\title{
SPATIAL PATTERNS OF ISLAMIC RELIGIOUS ACTIVITIES IN KRAPYAK DISTRICT, YOGYAKARTA
}

| Received June 25th, 2021 | Accepted October 4th, 2021 | Available online December 15th, 2021

DOI http://dx. doi. org/10.18860/jia.v6i4. 12575

\section{Rizky Adi Sudrajad}

Department of Architecture and Planning

Faculty of Engineering

Universitas Gadjah Mada

Indonesia

rizkysudrajad@gmail.com

\section{Bambang Hari Wibisono}

Department of Architecture and Planning

Faculty of Engineering

Universitas Gadjah Mada

Indonesia

wibisono@ugm.ac.id

\begin{abstract}
Krapyak District is one of the significant areas in Yogyakarta, crossed by the Philosophical Axis stretching from Tugu in the North to Panggung Krapyak in the South end. The Javanese philosophy of Sangkan Paraning Dumadi lies within the axis. In 2017, based on the Special Region of Yogyakarta Governor's Decree Number 108, this axis was designated as the part of the cultural heritage. As stated in the decree, the areas around the philosophical axis must represent the meaning of Sangkan Paraning Dumadi, both in terms of activities and spaces. Furthermore, the presence of Islamic boarding schools, also known as pesantren, helps to transform Krapyak District into a solid Islamic community. This study aims to identify the relation between activity patterns and the built environment in Krapyak District. The harmony between activity patterns, the built environment, and the meaning of a complex philosophical axis of Krapyak District is fascinating to investigate, especially in light of the district's environmental issues. This study used a deductive approach with a descriptive-qualitative method based on the behavioral space system model of place-centered mapping. It is concluded that there are three layers of activity and space, namely the religious layer, the socio-cultural layer, and the philosophical axis layer, that interact one another with some specific spatial patterns.
\end{abstract}

\section{KEYWORDS:}

Krapyak; philosophical axis; activity system; spatial pattern; behavioral space mapping; Islamic activities; pondok pesantren

\section{INTRODUCTION}

Islam has expanded throughout Indonesian culture through cultural and spiritual acculturation. The emergence of Islamic dynasties in Java Island is intrinsically related to Islam. The ancient monarchs formed Islamic kingdoms as a result of acculturation. Therefore, many vestiges of Islamic kingdoms, both environmental and cultural are preserved and spread throughout Indonesia [1].

The community believed they would receive a value that would materialize and become a feature in the community. This phenomenon can be found in the community's historical legacy and noble ideals, commonly portrayed in human behavioral patterns. The three essential parts of social life creation can be used to identify the ensuing forms of activity. Spradley mentions three important elements: people, space, and activity [2]. The combination of these three elements can produce a good observation of human activities and behavior. The pattern of human activity form certainly cannot be separated from the surrounding local wisdom. Likewise, the interaction between human and their environment is a manifestation of local wisdom which has existed since the ancient times and is still relevant to the development of science in the modern era [3].

Founded in 1755, Yogyakarta is the home of historical and cultural heritages that are still wellpreserved. One of the unique intangible heritages and identities of Yogyakarta is the Philosophical Axis connecting Tugu and Panggung Krapyak, which is a part of the imaginary axis that connects Mount Merapi in the North South Sea (Indian Ocean). This philosophical axis can also be interpreted visually from its physical configuration as a spatial arrangement of the ancient city of Yogyakarta. In 2017, based on the Special Region of Yogyakarta Governor's Decree Number 108 of 2017, the Philosophical Axis was established as a cultural heritage structure. The harmony between the environment around the Philosophical Axis and its meaning must be maintained. Panggung Krapyak is one of the buildings in the Krapyak District that was originally a forest in the South part of the palace, where Sultans spent leisure time or hunting.

In 1910, Krapyak Islamic Boarding School or 
Pondok Pesantren Krapyak was established by KH. Muhammad Munawwir in Krapyak District. In 1976, the name of the Islamic Boarding School was changed into Krapyak Al-Munawwir Islamic Boarding School. Many Islamic boarding schools continue to expand in the area, followed by the establishing various Islamicbased educations surrounding the Krapyak District. There are three major Islamic boarding schools in Krapyak District: Al-Munawwir Islamic Boarding School, Ali Maksum Islamic Boarding School, and Al-Muhsin Islamic Boarding School. Hadi et al. argues that Islamic boarding schools and religious activities must significantly affect the village or surrounding environment, ensuring that village development is also founded in the existing Islamic values and traditions [4].

Islamic religious activities, notably Islamic education activities in Krapyak District, have become more dynamic. As a result, the neighborhood's proximity to the activity centers influences its density, and the Krapyak District is becoming increasingly urbanized. There are 11 mosques, four prayer rooms (mushala), and one small prayer room (langgar) in Krapyak District. The number of worship places certainly accommodate the Krapyak community in religious activities. The worship space also accommodates various commonly socio-cultural activities for the community. The district is also considered as a part of the peri-urban area. According to Sofer, suburb space is vulnerable because it is situated in a transition zone between urban and rural activity, resulting in a 'gap' between migrants and indigenous people [5]. In contrast, Krapyak District has a high cultural and historical value, with Panggung Krapyak and the Krapyak Islamic Boarding Schools areas among the prominent elements.

Based on the previous mentioned facts, the followings are the research questions raised: (a) Based on the religious activities in the area, what is the spatial pattern shaped in the Krapyak District?; (b) Is the spatial pattern shaped in the Krapyak District still influenced by the characteristics of the environment?; (c) What is the pattern of community activities that have emerged as a result of the development of this area, and how is the local people's perspective of the development of Krapyak District? Thus, this study identifies the possibility of a relationship between religious activities in the Krapyak District and the spatial patterns shaped by these activities.

Krapyak District is a densely populated urban community settlement (kampung) with two large Islamic boarding schools in the outskirts of Yogyakarta. It is also a part of the Yogyakarta Urban Area agglomeration. Because it is situated in the middle of a community, pesantren has unique qualities, such as becoming united with communal activities, educational facilities, and worship facilities. In addition, they assist the community in participating in various Islamic religious events [6]. This study employed a grand theory provided by Spradley called the theory of locations, humans, and activities to observe the characteristics of the pesantren village in the Krapyak District. This concept will serve as one of the research's key theoretical foundations. Humans, spaces, and activities are the ideas of understanding that are related to social-cultural space, including places, humans, and activities [2].

According to Haryadi and Setiawan, the space that accommodates human activities has several restrictions. Humans are limited by their ability to reach a space known as the home range [7]. Webber, in Chapin Jr., emphasized his belief that the city is a dynamic system of activities in which the qualities of persons, organizations, institutions, and other interconnected elements play a role. Human relationships, physical form, and activity sites are three views that Webber used to explain the links among city activities [8]. A spatial clustering process based on the homogeneity of space characteristics occurs due to the system of activities. The perspectives of an individual or group on lifestyle and religious life can be tied to a spatial clustering process [9].

Individuals, families, and certain institutions form activity systems and the relationships among their behavioral patterns. They are still in progress. These activity systems are manifested in spatial patterns that have a meaning related to land use [8] [10]. Activity systems can be analyzed in several ways: time to carry out activities/time budgets, census activities, surveys, and knowledge of origin and destination [10]. Beside the study conducted based on general theories, we also considered the perspective of religious activities. In general, according to Hakim (2019), worship is divided into two, mahdhah and ghairu mahdhah. Mahdhah worship is a pure worship. The worship of ghairu mahdhah is an impure worship. Ghairu mahdhah worship, on the other hand, can become worship if the worshipper's intentions are seen and deliberated [11].

In order to identify the activity pattern, one of the methods used is the behavior setting approach, which provides an opportunity for us to be able to find out the social system that arises from the systematic behavior patterns of the environmental inhabitants. Rapoport expressed his view regarding the relationship between space and activity in an area. Rapoport mentioned three kinds of views, namely environmental determinism, possibilism, and probabilism [9]. In addition, Perin, in Lang, said that the activity systems in behavior settings consist of an arrangement of behavior circuits. Behavior circuits have a specific purpose and are distinguished through specific activities [10]. Furthermore, behavior settings and activity systems can form a unified pattern called behavior space systems related to spatial components: home range, territory, core area, and jurisdiction [9].

\section{RESEARCH METHOD}

This study explicitly observed the behavior of the space system in the Krapyak District. There were three Islamic boarding school foundations with 14 places of worship of two different affiliations. In 
addition, this area also has the value of the philosophical axis of Sangkan Paraning Dumadi. In order to examine the environmental setting of the Krapyak District, this research was carried out through the following stages.

a. The primary data was obtained from the results of field observation and in-depth interviews. The collection of primary data was carried out in 2019 in the form of activities at each point of Islamic religious activities in Krapyak District, accompanied by secondary data collected from the government, literature, internet, and other various sources. Islamic religious activities were observed in 11 mosques, three prayer rooms, one langgar, and three Islamic boarding schools;

b. The data collection and display used the behavioral space system method, in the form of place-centered mapping set at locations where Islamic religious activities take place;

c. The data processing and discussion used the descriptive-qualitative method and conclusions were drawn using the triangulation method.

\section{RESULTS AND DISCUSSION}

The study addresses four sections to assess the environmental setting of the Krapyak District based on the results of the survey, analysis, and data processing. These are the Krapyak District's activities, activity systems, and built physical environment. This research aims to show the relation between the Krapyak District's environmental conditions, the meaning of the Sangkan Paraning Dumadi, and the philosophical axis.

\section{ISLAMIC RELIGIOUS ACTIVITIES IN KRAPYAK DISTRICT}

According to the Minister of Religion of the Republic of Indonesia quoted in NU Online, Islamic religious activities are divided into three levels of sharia
[12]. These activities are performed in the Krapyak District. They are divided into two parts: Islamic religious activities level 1 and 2 and Islamic religious activities level 3, as shown in Table 1 and Table 2 below.

\begin{tabular}{|c|c|c|}
\hline No. & Religious Activities & Period \\
\hline \multirow[t]{5}{*}{1} & Prayer (Sholat) & 5 times a day \\
\hline & & Nighttime \\
\hline & & Friday \\
\hline & & Hari Raya (Islamic \\
\hline & & Festivals) \\
\hline \multirow[t]{4}{*}{2} & Quran Recitation & Daily \\
\hline & & Weekly \\
\hline & & Monthly \\
\hline & & Annually \\
\hline \multirow[t]{2}{*}{3} & $\begin{array}{l}\text { Islamic Festivals } \\
\text { Celebration }\end{array}$ & Eid al-Fitr \\
\hline & & Eid al-Adha \\
\hline 4 & Zakat al-Fitr & Annually \\
\hline
\end{tabular}

Source: Survey results and analysis, [13]

Table 2. Islamic religious activities Level 3

\begin{tabular}{cl}
\hline No. & \multicolumn{1}{c}{ Religious Activities } \\
\hline 1 & Semaan (reciting and listening to Quran) \\
2 & Mujahadah (dhikr and pray) \\
3 & Sholawat Diba' (pray for the prophet) \\
4 & Reading Yasin and Tahlil \\
5 & Kitab Kuning (yellow book) Study \\
6 & Nyadran (Grave Visit) \\
7 & Haul (death anniversary) \\
8 & Zakat al- Fitr \\
\hline
\end{tabular}

Source: Survey results and analysis, [13]

The step was followed by mapping the actions with the highest intensity from the numerous activities indicated above. The intensity of Islamic religious activity in the Krapyak District is depicted in Table 3.

Table 3. The intensity of Periodic Islamic Activities in Krapyak District

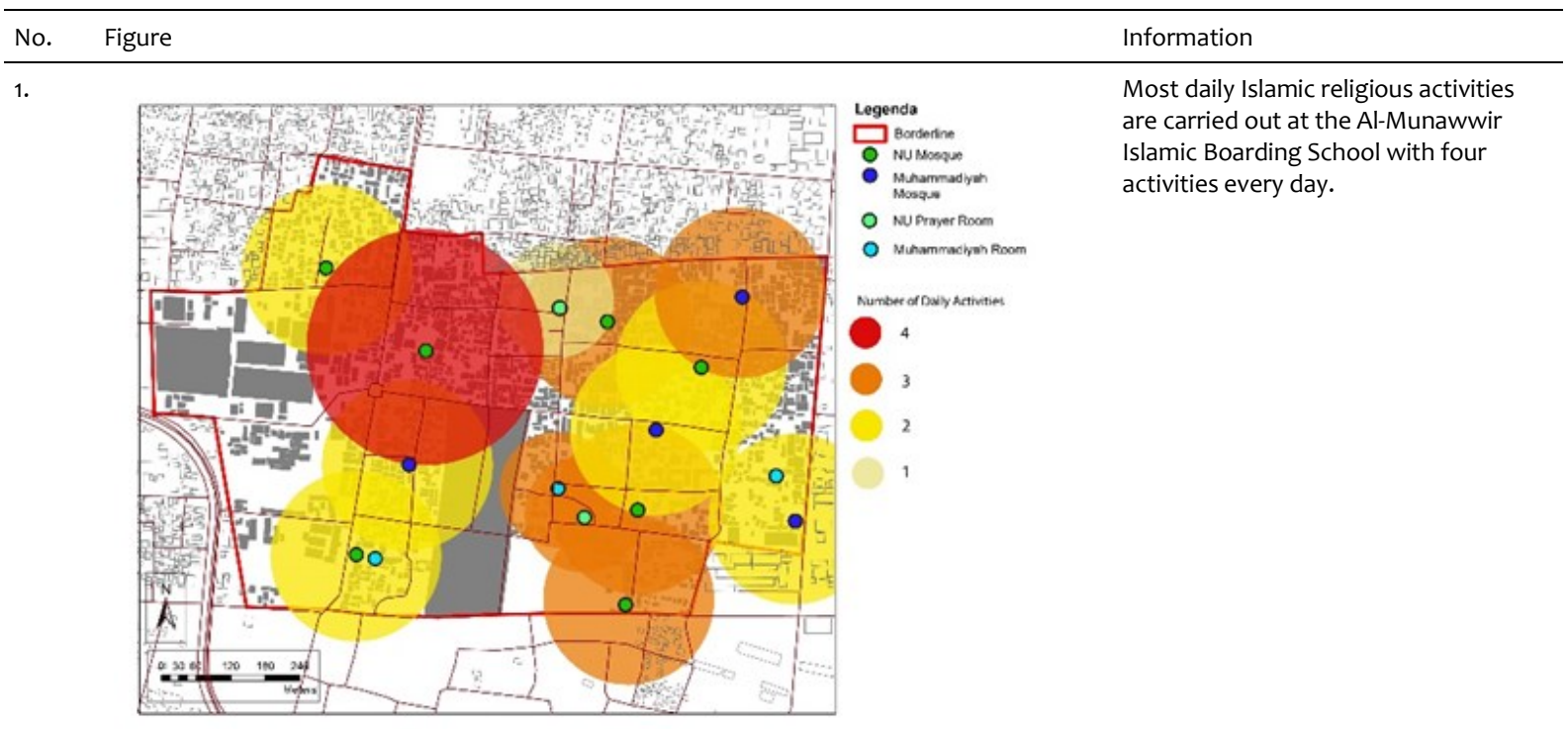



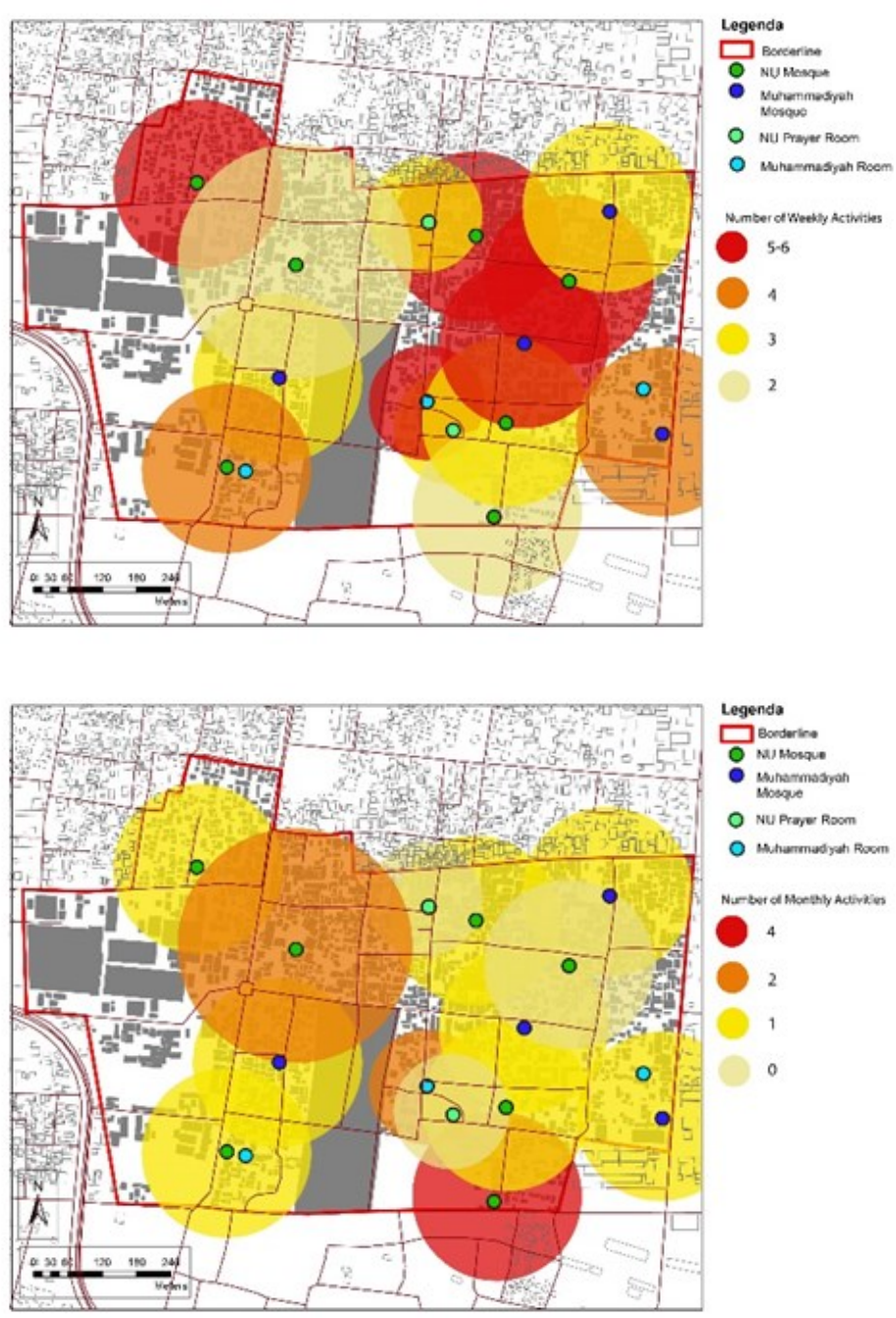

4.

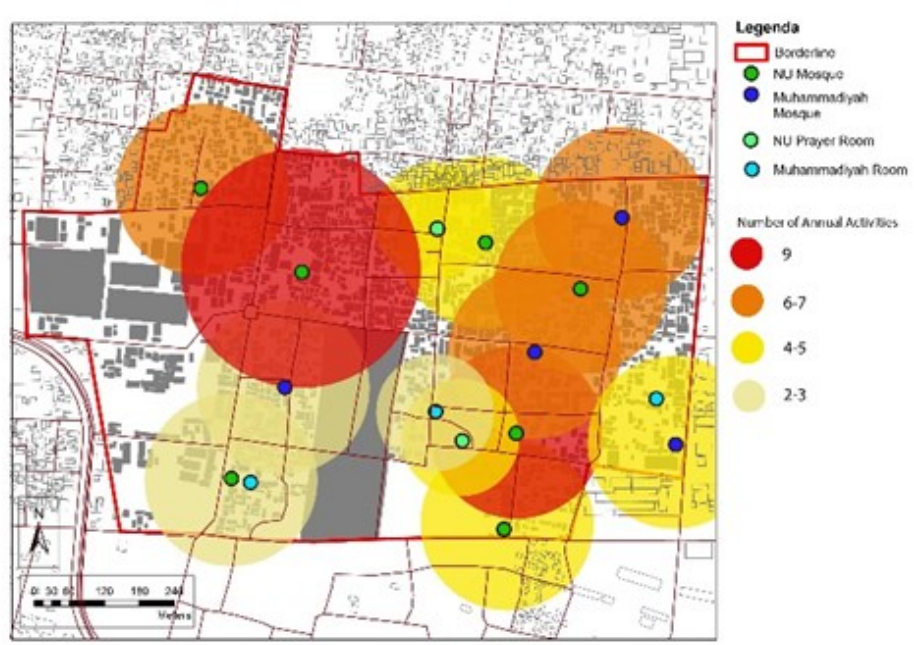

Most weekly Islamic religious activities are carried out in community mosques with a range of five to six activities per week.

Most monthly Islamic religious activities are carried out at the $\mathrm{Al}$ Mustofa Mosque with four activities per month.

Most annual Islamic religious activities are carried out at the Al-Munawwir Islamic Boarding School Mosque and the Al-Muhsin Islamic Boarding School Mosque with nine activities each year. 
Rizky Adi Sudrajad, Bambang Hari Wibisono

The variety of activities with different levels of sharia and the implementation period arises due to the existence of two affiliations in society: NU and Muhammadiyah. These two affiliations create the public's perspective on Islamic religious activities. Even though they are different in many aspects, the Krapyak community is still based on Islamic law. Krapyak District has seven mosques with NU affiliation, four mosques with Muhammadiyah affiliation, one langgar affiliated with $\mathrm{NU}$, and two mushollas affiliated with Muhammadiyah. Each of these worship places also has its service areas based on the majority of the congregation from the neighborhood unit (RT) around the worship places. Figure 1 shows an overview of worship places and their service areas.

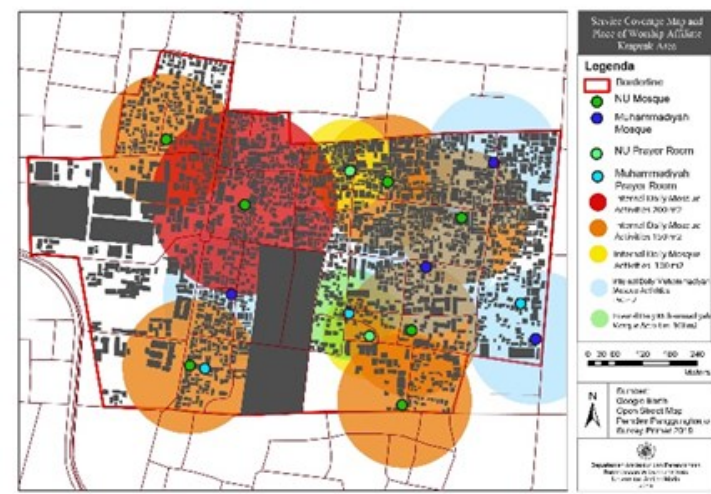

Figure 1. The Map of Service Areas and the Affiliation of the Worship Places in Krapyak District Source: Authors' analysis, [13]

\section{SOCIAL-CULTURAL INTERACTION IN THE ISLAMIC RELIGIOUS ACTIVITIES}

This section discusses the socio-cultural interaction resulted from Islamic religious activities in the Krapyak District using the behavioral space systems method. The phenomenon is found in the interaction among various points of Islamic religious activities in mosques, prayer rooms, Islamic boarding schools, and the people of the Krapyak District. The following Table 4 shows the types of interactions that occur in the Krapyak District.

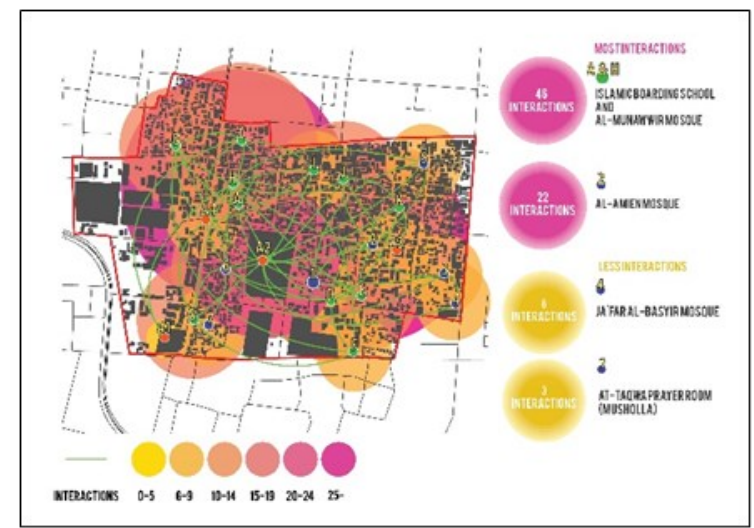

Figure 2. The elaboration of Islamic Religious and Social Activity Nodes

Source: Authors' analysis, [13]
Table 4. Interactions among Islamic Religious Activities

\begin{tabular}{|c|c|c|}
\hline No. & Type of Interactions & Note \\
\hline 1. & $\begin{array}{l}\text { Young and Old Amaliyah } \\
\text { Recitation }\end{array}$ & $\begin{array}{l}\text { Interaction among } \\
\text { mosques }\end{array}$ \\
\hline 2. & $\begin{array}{l}\text { Safinatullah Mosque and Al } \\
\text {-Hasanah Musholla } \\
\text { Construction History }\end{array}$ & $\begin{array}{l}\text { Interaction among } \\
\text { mosques }\end{array}$ \\
\hline 3. & Friday Prayer Activity & $\begin{array}{l}\text { Interaction among } \\
\text { mosques }\end{array}$ \\
\hline 4. & Eid al-Fitr Takbir Activity & $\begin{array}{l}\text { Interaction among } \\
\text { mosques }\end{array}$ \\
\hline 5. & Eid al-Adha Takbir Activity & $\begin{array}{l}\text { Interaction among } \\
\text { mosques }\end{array}$ \\
\hline 6. & Mujahadah Activity & $\begin{array}{l}\text { Interaction among } \\
\text { mosques }\end{array}$ \\
\hline 7. & $\begin{array}{l}\text { Muhammadiyah Routine } \\
\text { Recitation Activity }\end{array}$ & $\begin{array}{l}\text { Interaction among } \\
\text { mosques }\end{array}$ \\
\hline 8. & Eid al-Adha Activity & $\begin{array}{l}\text { Interaction among } \\
\text { mosques }\end{array}$ \\
\hline 9. & $\begin{array}{l}\text { Eid al-Fitr Activity (Zakat } \\
\text { Fitrah) }\end{array}$ & $\begin{array}{l}\text { Interaction among } \\
\text { mosques }\end{array}$ \\
\hline 10. & $\begin{array}{l}\text { Al-Hasanah Musholla dan } \\
\text { Ja'far Al-Basyir Mosque } \\
\text { Congregation }\end{array}$ & $\begin{array}{l}\text { Interaction among } \\
\text { mosques }\end{array}$ \\
\hline 11. & $\begin{array}{l}\text { Muhammadiyah Annual } \\
\text { Activity }\end{array}$ & $\begin{array}{l}\text { Interaction among } \\
\text { mosques }\end{array}$ \\
\hline 12. & Funeral Activity & $\begin{array}{l}\text { Interaction among } \\
\text { mosques }\end{array}$ \\
\hline 13. & $\begin{array}{l}\text { Majelis Semaan Haul } \\
\text { Activity }\end{array}$ & $\begin{array}{l}\text { Interaction between } \\
\text { Islamic boarding schools } \\
\text { and mosque }\end{array}$ \\
\hline 14. & $\begin{array}{l}\text { Islamic Boarding Schools } \\
\text { with Muhammadiyah } \\
\text { Mosque Activity }\end{array}$ & $\begin{array}{l}\text { Interaction between } \\
\text { Islamic boarding } \\
\text { schools and mosques }\end{array}$ \\
\hline 15. & $\begin{array}{l}\text { Islamic Boarding Schools } \\
\text { with NU Mosque }\end{array}$ & $\begin{array}{l}\text { Interaction between } \\
\text { Islamic boarding } \\
\text { schools and mosques }\end{array}$ \\
\hline 16. & $\begin{array}{l}\text { Al-Munawwir Islamic } \\
\text { Boarding School with } \\
\text { Kodama Mosque }\end{array}$ & $\begin{array}{l}\text { Interaction between } \\
\text { Islamic boarding } \\
\text { schools and mosques }\end{array}$ \\
\hline 17. & $\begin{array}{l}\text { Islamic Boarding School } \\
\text { with Al-Mustofa Mosque }\end{array}$ & $\begin{array}{l}\text { Interaction between } \\
\text { Islamic boarding } \\
\text { schools and mosques }\end{array}$ \\
\hline 18. & $\begin{array}{l}\text { Ali Maksum Islamic } \\
\text { Boarding School with Jami' } \\
\text { Al-Munawwir Mosque }\end{array}$ & $\begin{array}{l}\text { Interaction between } \\
\text { Islamic boarding } \\
\text { schools and mosques }\end{array}$ \\
\hline 19. & $\begin{array}{l}\text { Haul Activity Interaction } \\
\text { between Islamic boarding } \\
\text { schools }\end{array}$ & $\begin{array}{l}\text { Interaction between } \\
\text { Islamic boarding } \\
\text { schools }\end{array}$ \\
\hline 20. & Muharram Activity & $\begin{array}{l}\text { Interaction between } \\
\text { Islamic boarding } \\
\text { schools }\end{array}$ \\
\hline 21. & Santri Daytime Activity & $\begin{array}{l}\text { Interaction between } \\
\text { Islamic boarding } \\
\text { schools }\end{array}$ \\
\hline \multirow[t]{2}{*}{22.} & Syawalan Dukuh Activity & $\begin{array}{l}\text { Interaction among } \\
\text { people }\end{array}$ \\
\hline & $\begin{array}{l}\text { Neighborhood Syawalan } \\
\text { Activity }\end{array}$ & $\begin{array}{l}\text { Interaction among } \\
\text { people }\end{array}$ \\
\hline 23. & Village Merti Activity & $\begin{array}{l}\text { Interaction among } \\
\text { people }\end{array}$ \\
\hline
\end{tabular}

Source: Author's analysis, [13]

When the interactions are mapped, it shows that the Islamic Boarding School and Al-Munawwir Mosque have the greatest interactions, with a total of 46 interactions. The elaboration of interconnections between activities in the Krapyak District is depicted in Figure 2. 
The following analysis focuses on the interaction between these points, which results in a pattern of Islamic religious activities in Krapyak. The type of interaction that takes place: (a) gathers to a single point, and (b) spreads from one point to other locations. From this form of interaction, Islamic boarding school and Al-Munawwir Mosque become the center and driving force of Islamic religious activities in the Krapyak District. The following Table 5 presents the form or type and number of interactions in the Krapyak district.

Table 5. Number and Form/Type of Islamic Religious Activity Interactions in Krapyak District

\begin{tabular}{cllc}
\hline No. & \multicolumn{2}{c}{ Form/Type of Interactions } & Number \\
\hline 1. & Centred & Tolerance Form Value & 1 \\
& activities & Complimentary & 7 \\
& & Together & 8 \\
& & Alternating & 1 \\
\hline 2. & Spread/ & Complimentary & 4 \\
& spatially & Tolerance & 1 \\
\hline 3. & distributed & Historic & Service Needs \\
& & Islamic Boarding School & 1 \\
& & Influence & 2
\end{tabular}

Source: Authors' Analysis, [13]

Based on the diagram, the pattern of sociocultural activities interaction in the system of Islamic religious activities that occur in the Krapyak District is illustrated in Figure 3 below.

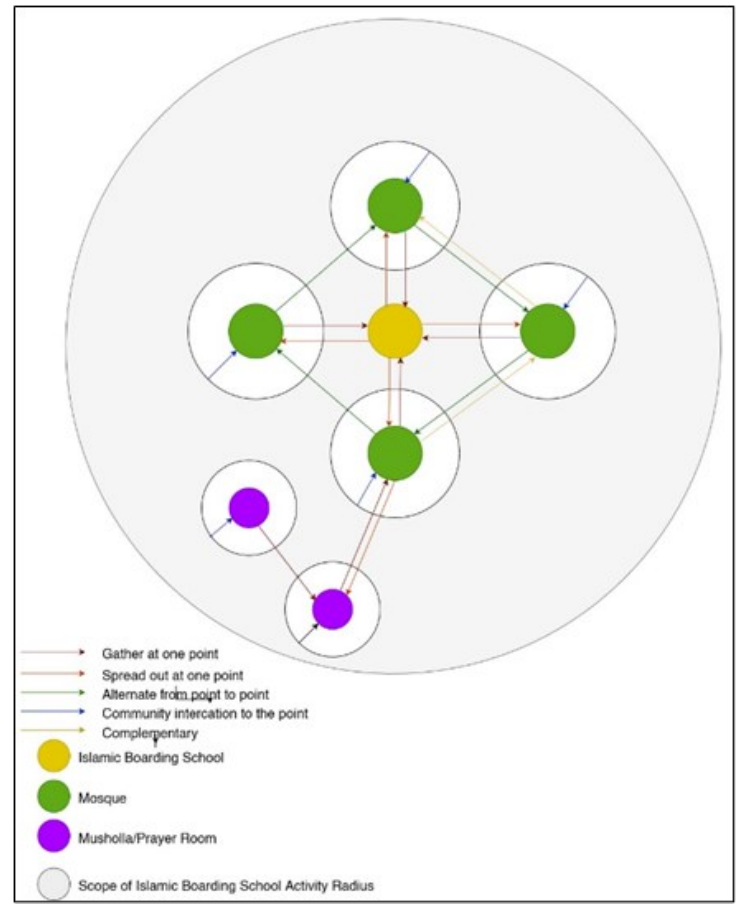

Figure 3. Social-Cultural Interaction Pattern of the Islamic Religious Activity System in Krapyak District Source: Authors' analysis, [13]
As illustrated in Figure 3, Islamic boarding schools tend to be the central driving force of Islamic religious activities in the Krapyak District. The AlMunawwir Islamic Boarding School serves as the main point for various religious events, including syawalan and haul of $\mathrm{KH} \mathrm{M}$ Munawwir. This boarding school continued to grow and was filled with various Islamic religious activities in mosques within the scope of observation of the Krapyak District through the role of teachers (kyai) and their students. In addition, mosques in Krapyak District also have various social interactions, characterized by alternating the locus of the activities from one place to another. Likewise, there are complementary activities. If one mosque is not available, activities can be carried out in other mosques within the scope of the Krapyak District.

\section{SPATIAL PATTERNS IN KRAPYAK DISTRICT}

The shape and physical nature of the space in the study area must be considered when determining the environmental setting. In the following discussion, the geographical morphology of the Krapyak District will be seen from the radius delineation of the sites with the highest activity intensity that ranges from daily to annual. According to morphological components of space such as building intensity, road network patterns, building functions, and components of Islamic settlements, the internal service radius of Islamic Boarding Schools and Al-Munawwir Mosque has the strongest Islamic settlement character in Krapyak District. Some of the morphological attributes of the area's space are shown in Figure 4 (af)

(a) Building Intensity (Floor Area Ratio)

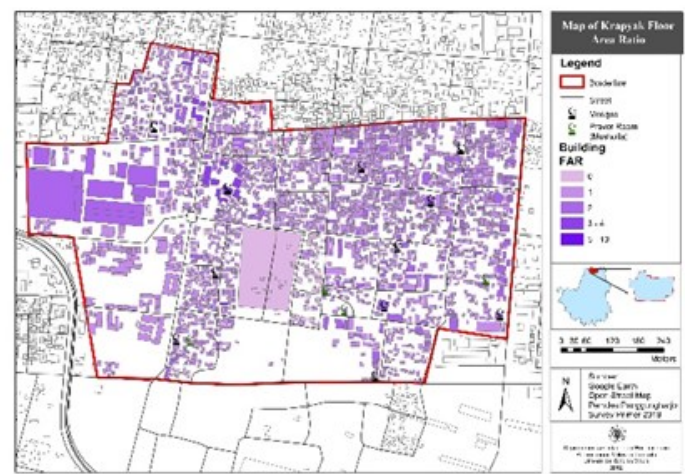

(b) Building Coverage Ratio 

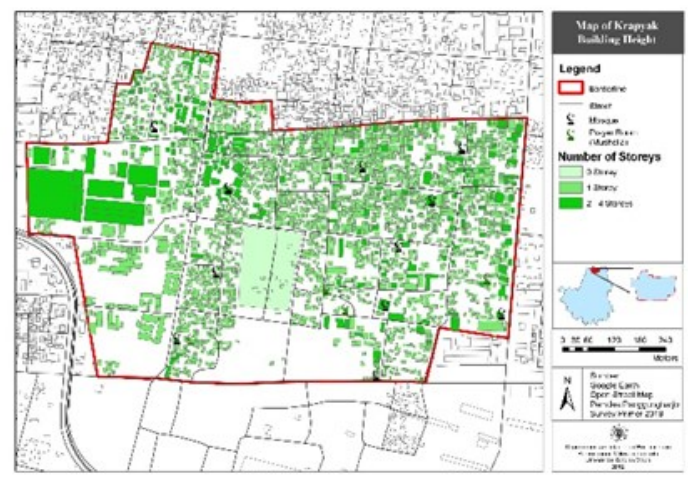

(c) Building Height

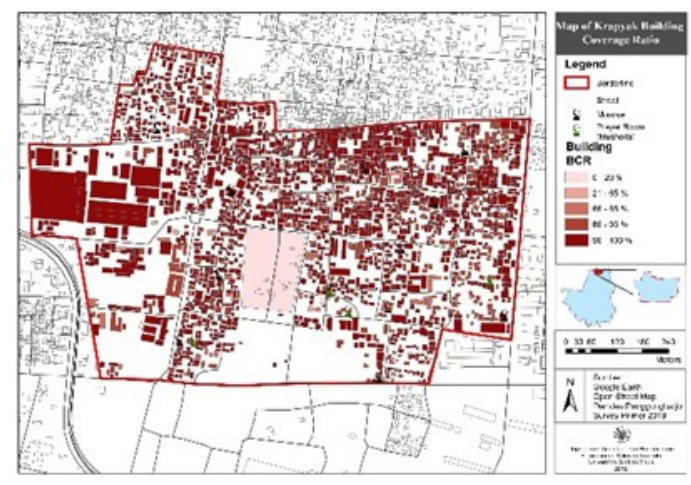

(d) Building Function

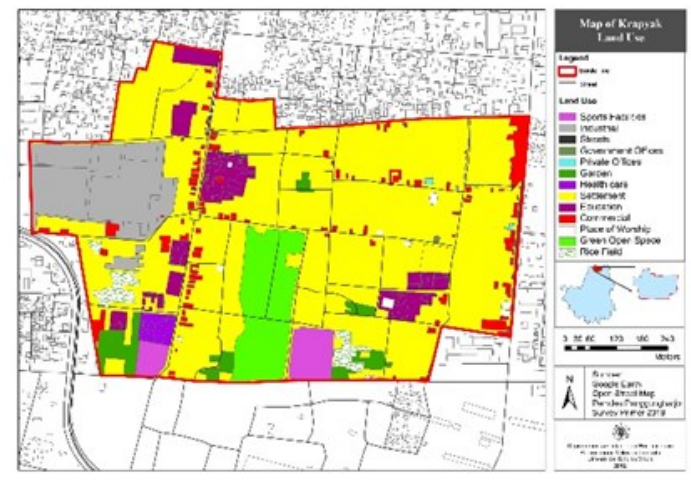

(e) Road Network and Activity Distribution

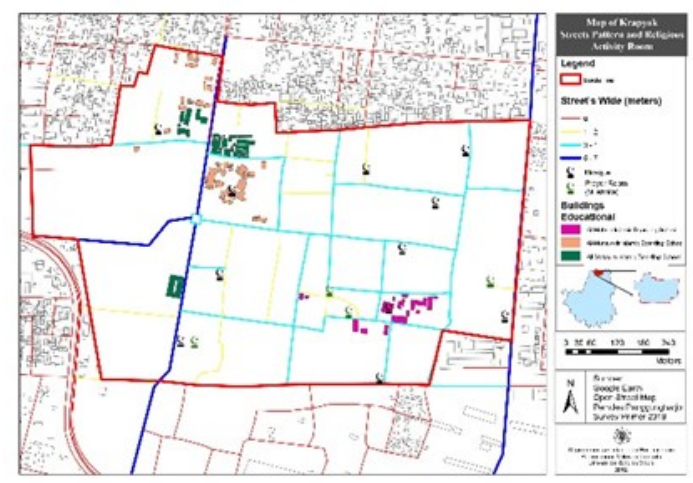

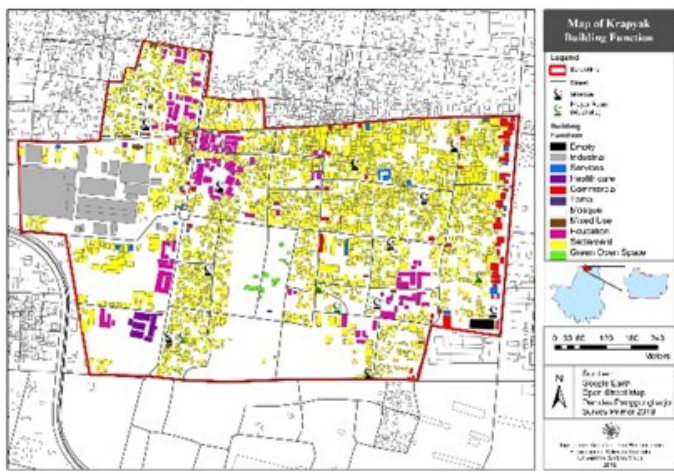

Figure 4. Space Morphological Attributes of the Krapyak Region Source: Authors' Analysis [13]

The six spatial morphological attributes of the area mentioned above can be classified based on the type of building, as can be seen in the following Table 6.

Table 6. Classification based on Building Types in Krapyak District

\begin{tabular}{cllll}
\hline No. & Building Types & \multicolumn{1}{c}{ Functions } & BCR & FAR \\
\hline 1 & Residential & Residential, & $81-$ & $1<$ \\
& Type 1 & Education, and & $100 \%$ & \\
& (Very Dense) & Worship & & \\
\hline 2 & Residential & Residential, & $81-$ & 0.81 \\
& Type 2 & Education, and & $100 \%$ & -1 \\
& (Dense) & Worship & & \\
\hline 3 & Residential & Residential, & $61-$ & 0.61 \\
& Type 3 & Education, and & $80 \%$ & - \\
& (Standard) & Worship & & 0.8 \\
\hline 4 & Residential & Residential & $0-$ & $0-$ \\
& Type 4 & place, & $60 \%$ & 0.6 \\
& (Low) & Education, and & & \\
& & Worship & & \\
\hline 5 & Commercial & Commercial, Mix & $81-$ & $1<$ \\
& Type 1 & use, and Service & $100 \%$ & \\
& (Very Dense) & & & \\
\hline 6 & Commercial & Commercial, Mix & $81-$ & 0.81 \\
& Type 2 & use, and Service & $100 \%$ & -1 \\
& (Dense) & & & \\
\hline
\end{tabular}

Note: BCR: Building Coverage Ratio; FAR: Floor Area Ratio Source: Author's analysis, [13]

Buildings in Krapyak District are classified according to their intensity and function. First, it aims to identify the density level of every delineation followed by the delineation considering the distance between the activity points and from the daily to annual activity intensity, with the highest values. The result of important point delineation can be seen in Figure 5.

(f) Land Use 


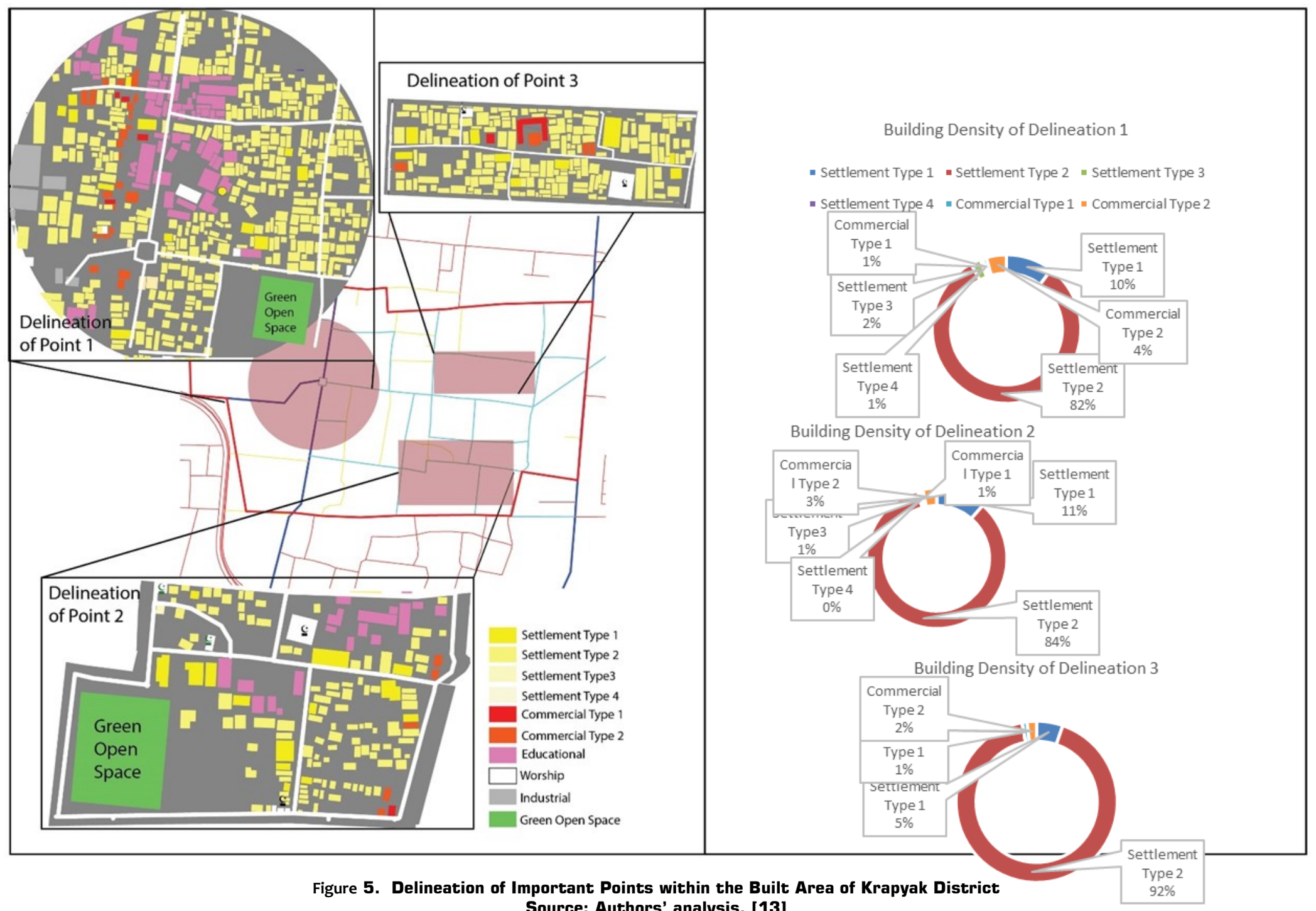

Spatial Patterns of Islamic Religious Activities in Krapyak District, Yogyakarta 
When analyzed from the density in general, most of these three areas have the same average density and dominant building functions. However, when observed using the components of Islamic settlements, the area in delineation 1 has the most attributes. It leads to a result that Al-Munawwir Islamic Boarding School Area has the most visible impact on the morphological and spatial character of the area. The Islamic space attributes of each space unit can be identified and summarized in Table 7.

Table 7. Analysis of Islamic Space Attributes

\begin{tabular}{|c|c|c|c|c|c|c|}
\hline \multirow[t]{2}{*}{ No } & \multirow{2}{*}{$\begin{array}{l}\text { Islamic } \\
\text { Activity } \\
\text { Space }\end{array}$} & \multicolumn{5}{|c|}{ Islamic Space Attribute } \\
\hline & & $\begin{array}{c}\text { Mosque } \\
\text { Available }\end{array}$ & $\begin{array}{l}\text { Commercial } \\
\text { Activity } \\
\text { Gathering }\end{array}$ & $\begin{array}{l}\text { Islamic } \\
\text { Education }\end{array}$ & $\begin{array}{l}\text { Open } \\
\text { Spaces }\end{array}$ & $\begin{array}{c}\text { Mosque } \\
\text { as Public } \\
\text { Spaces }\end{array}$ \\
\hline 1. & $\begin{array}{c}\text { Delineation } \\
\text { of Point } 1\end{array}$ & $v$ & $v$ & $v$ & $v$ & $v$ \\
\hline 2. & $\begin{array}{c}\text { Delineation } \\
\text { of Point } 2\end{array}$ & $v$ & & $v$ & $v$ & $v$ \\
\hline 3. & $\begin{array}{l}\text { Delineation } \\
\text { of Point } 3\end{array}$ & $v$ & & $v$ & & $v$ \\
\hline
\end{tabular}

Source: Authors' analysis, [13]

ISLAMIC RELIGIOUS ACTIVITIES IN KRAPYAK DISTRICT AND THE MEANING OF PHILOSOPHICAL AXIS

The philosophical axis runs through the Krapyak District, making it a unique location. The presence of Islamic boarding school complexes with intense Islamic activities gives its prominent value to the area. The environmental setting of the Krapyak, consisting of the activities, activity systems, and spatial morphology, can be associated with this unique remark. The following discussion will demonstrate how Krapyak District's environmental context corresponds to Sangkan Paraning Dumadi's meaning in Philosophical Axis. The discussion is based on the relevant laws and regulations. It includes the physical boundaries of the corridor along KH Ali Maksum Road, which is also a part of the core zone of the philosophical axis. Then, the activities along the corridor and the Islamic education activities should also be considered. This step is primarily intended to identify anything that could disrupt the balance of activities and spaces.

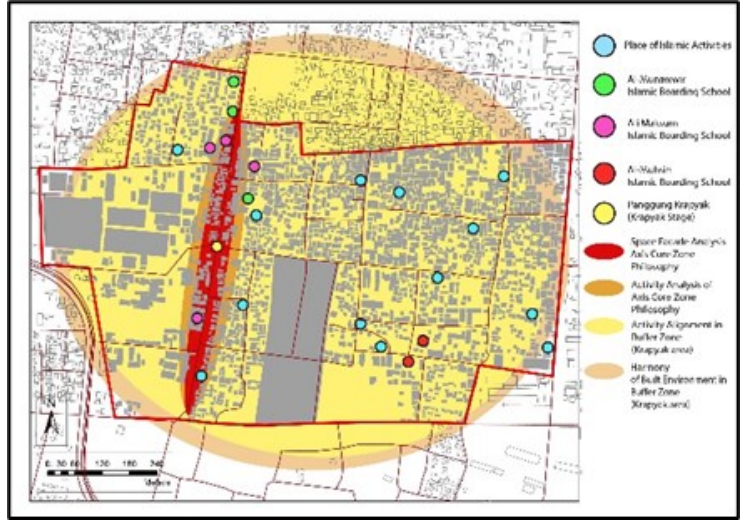

Figure 6. Observation Area to Identify the Harmony between Krapyak District and the Philosophical Axis Source: Authors' analysis
The following Table 8 presents the study of several documents in the form of regulations and provisions applied in the Yogyakarta Area related to the alignment of the philosophical axis. The results of this study are used to analyze the compatibility between the distinctive features of the Krapyak District and the regulations regarding it.

Table 8. Regulations and Provisions Related to Philosophical Axis

\begin{tabular}{|c|c|c|}
\hline No. & Related Law and Regulations & Description \\
\hline 1. & $\begin{array}{l}\text { Governor of Daerah Istimewa } \\
\text { Yogyakarta's Decree Number } \\
108 \text { of } 2017\end{array}$ & $\begin{array}{l}\text { Philosophical axis } \\
\text { determination as a cultural } \\
\text { heritage structure. }\end{array}$ \\
\hline 2. & $\begin{array}{l}\text { Special Local Regulations } \\
\text { Number } 2 \text { of } 2017\end{array}$ & $\begin{array}{l}\text { Krapyak District is } \\
\text { designated as the Sultanate } \\
\text { Strategic Space Unit on } \\
\text { Keprabon Land. } \\
\text { Accordingly, the area } \\
\text { spatial arrangement is } \\
\text { adjusted to the } \\
\text { philosophical axis meaning. }\end{array}$ \\
\hline 3. & $\begin{array}{l}2016 \text { Integrated Plan and } \\
\text { Medium Term Specialty } \\
\text { Strategic Area }\end{array}$ & $\begin{array}{l}\text { Philosophical axis spatial } \\
\text { elements in Krapyak must } \\
\text { be preserved. }\end{array}$ \\
\hline 4. & $\begin{array}{l}2014 \text { Yogyakarta Urban } \\
\text { Cultural Area Master Plan }\end{array}$ & $\begin{array}{l}\text { Spatial planning must } \\
\text { represent the human life } \\
\text { cycle philosophy process in } \\
\text { accordance with the vision } \\
\text { and direction of } \\
\text { philosophical axis area } \\
\text { preservation. }\end{array}$ \\
\hline 5 . & $\begin{array}{l}\text { Sewon District Detailed Layout } \\
\text { Plan (RDTR) }\end{array}$ & $\begin{array}{l}\text { At the detailed layout plan } \\
\text { (RDTR) level in Sewon } \\
\text { District, the Krapyak District } \\
\text { is included in zoning with a } \\
\text { text planned to support } \\
\text { urban needs such as hotels, } \\
\text { nightclubs, and apartments. }\end{array}$ \\
\hline
\end{tabular}

Table 9. Potentials and Problems in Krapyak District According to the Activities and Space Linked to the Meanings of Philosophical Axis

\begin{tabular}{|c|c|c|}
\hline No. & Potential & Description \\
\hline 1. & $\begin{array}{l}\text { Activity in } \\
\text { Krapyak } \\
\text { District of } \\
\text { Islamic } \\
\text { Activity } \\
\text { System }\end{array}$ & $\begin{array}{l}\text { Krapyak District is intensely } \\
\text { characterized by Islamic activities with } \\
\text { two affiliations, NU and } \\
\text { Muhammadiyah. Islamic activity center } \\
\text { in the area is located at the Al- } \\
\text { Munawwir Islamic Boarding School. }\end{array}$ \\
\hline 2. & $\begin{array}{l}\text { Built } \\
\text { Environmen } \\
\text { t in Krapyak } \\
\text { District }\end{array}$ & $\begin{array}{l}\text { Krapyak District has three Islamic } \\
\text { Boarding School Foundations with } \\
\text { various Islamic educational } \\
\text { institutions. Therefore, there are } \\
\text { plenty of Islamic spaces in this area, } \\
\text { where Krapyak Islamic Boarding } \\
\text { School is located. }\end{array}$ \\
\hline 3. & $\begin{array}{l}\text { KH Ali } \\
\text { Maksum } \\
\text { Road } \\
\text { Hallway }\end{array}$ & $\begin{array}{l}\text { The main access road is also a part of } \\
\text { the philosophical axis, along which } \\
\text { some educational functions and } \\
\text { various supporting functions are } \\
\text { located. Furthermore, starting from } \\
\text { the Northern part of the delineation to } \\
\text { the South of Panggung Krapyak, this } \\
\text { road is also often used for Islamic } \\
\text { activities such as haul activities and } \\
\text { village merti. }\end{array}$ \\
\hline
\end{tabular}




\begin{tabular}{cll}
\hline No. & Problems & \multicolumn{1}{c}{ Description } \\
\hline 1. & Sewon & Detailed Layout Plan (RDTR) is still \\
& $\begin{array}{l}\text { District } \\
\text { Detailed } \\
\text { toyout } \\
\text { Plan }\end{array}$ & $\begin{array}{l}\text { district level. Thus, Krapyak District } \\
\text { can lose its identity as an Islamic } \\
\text { boarding school area and Islamic }\end{array}$ \\
(RDTR) & $\begin{array}{l}\text { Area. } \\
\text { Population } \\
\text { Growth }\end{array}$ & $\begin{array}{l}\text { Located in the city outskirts, the } \\
\text { area also undergoes a continuously } \\
\text { increasing population growth every } \\
\text { year. The increase in population } \\
\end{array}$ \\
& $\begin{array}{l}\text { along with the lack of strong rules } \\
\text { that bind the region can increase the } \\
\text { secularity of the Krapyak region }\end{array}$ \\
& &
\end{tabular}

Source: Authors' Analysis

Table 9 summarizes the potentials and problems in Krapyak District according to activities and space linked to the meaning of the philosophical axis. This analysis shows that Krapyak District and its alignment with the philosophical axis, Sangkan Paraning Dumadi, are correlated. This area also can make this harmony continues with the existence of Islamic boarding schools and various Islamic activities. However, the problem that could threaten this harmony and sustainability is the regulations, specifically Sewon District RDTR, which is less detailed in regulating the zoning permit for Krapyak District. Figure 7 below shows a chart that explains the efforts to actualize the sustainability of the harmony of Krapyak District with the meaning of the philosophical axis.

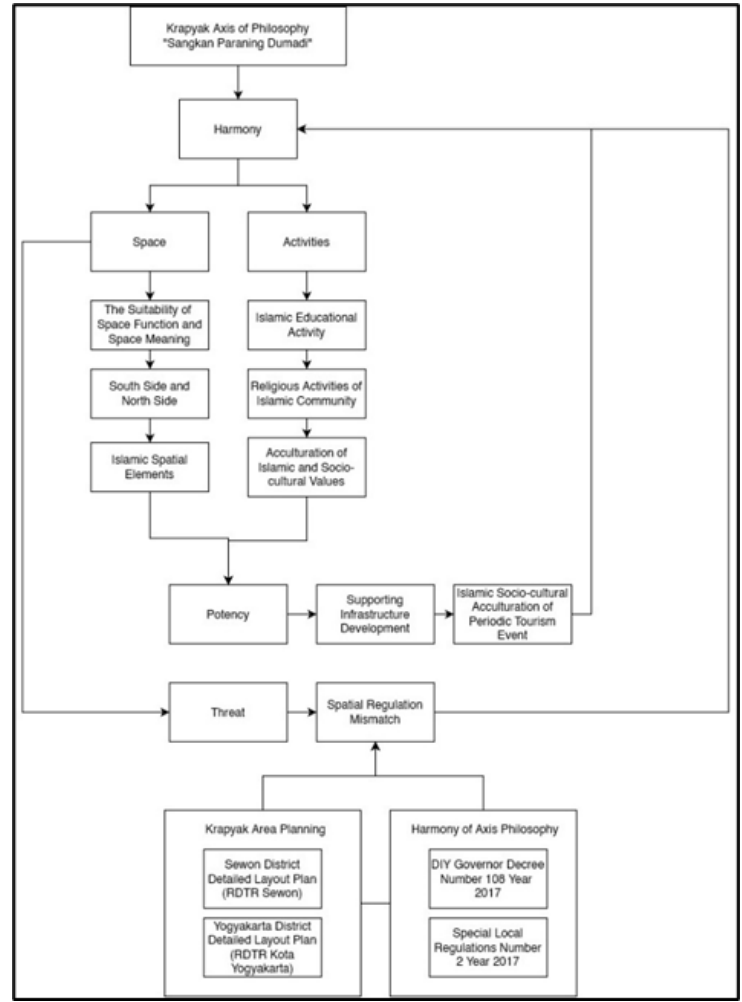

Figure 7. Harmony between the Meanings of Krapyak District and the Sangkan Paraning Dumadi Philosophical Axis Source: Authors' analysis, [13]
It is clear based on this discussion that the misalignment of the Krapyak District's local legislation with the meaning of the philosophical axis and the related RDTR can potentially transform Krapyak District into a less unique area. As a result, Krapyak District can also lose its Islamic character. In addition, it can be described that there are several layers of religious, socio-cultural, and philosophical axes in the Krapyak district, some of which overlap spatially, as can be seen in Figure 8. The religious layers are well preserved and are divided into two based on the values held by the community, namely NU and Muhammadiyah. The Al-Munawwir Islamic Boarding School initiated the layer of socio-cultural interaction. The philosophical axis layer is seen from the harmony between activities and the environment concerning the meaning of the philosophical axis in the core zone and supporting the cultural heritage structure of Yogyakarta City. Thus, in Krapyak District, the three levels effectively support each other and create a distinct socio-cultural feature. 


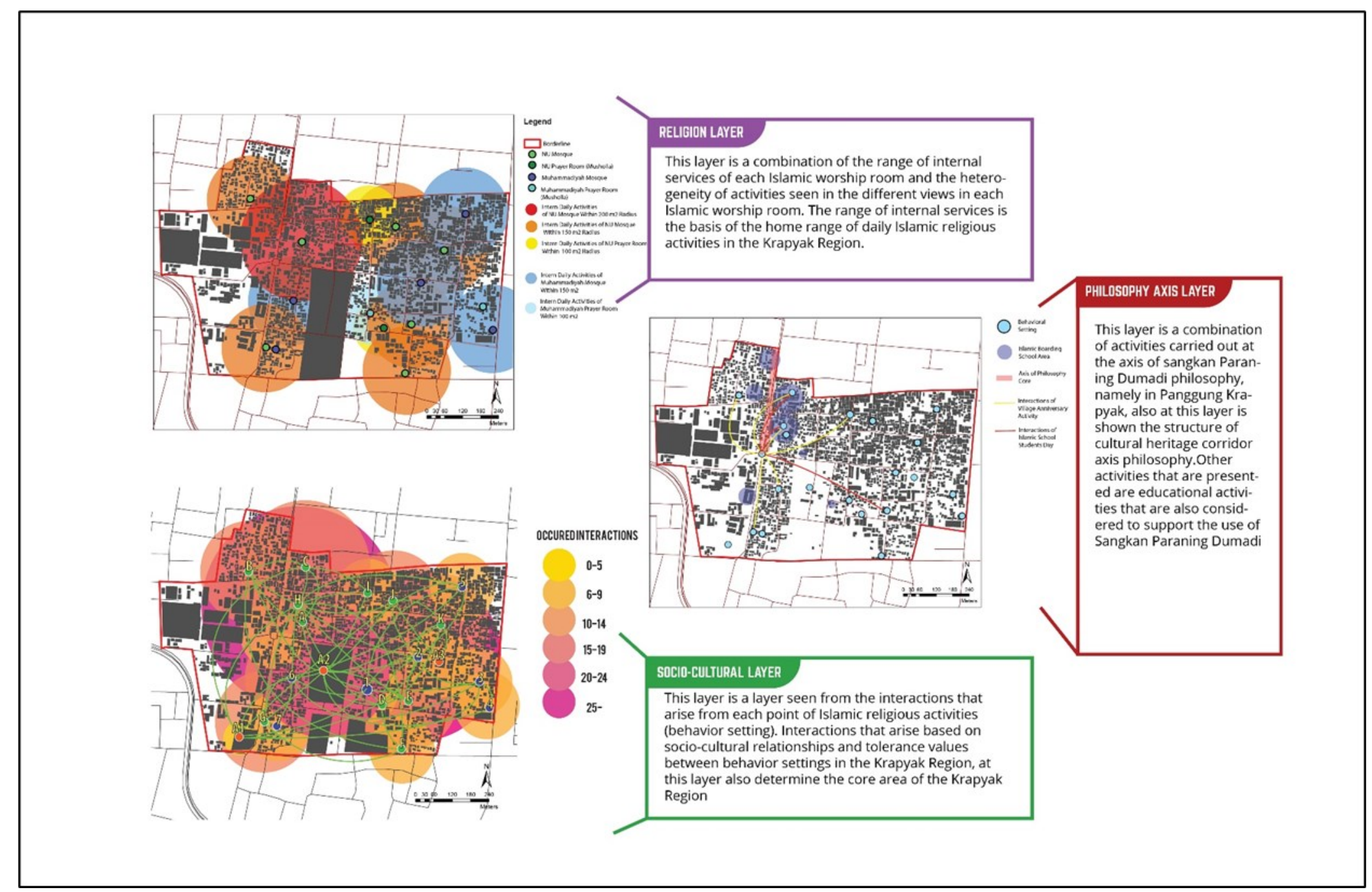

Figure 8. Layers of Religious and Social-Cultural Activities, and the Meanings of Philosophical Axis in Krapyak District Source: Authors' analysis, [13] 


\section{CONCLUSION}

Based on the Islamic activities and the environment, Krapyak District can be divided into three layers of activity systems, i.e., the religious layer, the socio-cultural layer, and the philosophical axis layer. These three layers create a harmonious environmental system. None of the Krapyak community's activities and values contradicts each other, instead of creating harmony in variety in the Krapyak District. In accordance with the religious perspective, Islamic religious activities are still maintained well in the Krapyak District. Islamic religious practices are still carried out at designated areas within the district. The interaction between religious activities also affects the socio-cultural conditions in Krapyak District. In terms of socio-cultural interaction, the form of interaction, and built environment system, their interaction allows the generation of the spatial character of this particular peri-urban region. In those layers, the AlMunawwir Islamic Boarding School acts as the main ignition point for Islamic religious activities in Krapyak District.

The local community maintains its Islamic identity by adapting numerous socio-cultural activities and incorporating Islamic principles into them. Concerning the third layer, i.e., the philosophical axis layer, this research studies the character of the built environment space within the context of Islamic religious activities in the Krapyak District. It can be seen from these two characteristics that there is still harmony between the two aspects and the philosophical axis' meaning. The challenge comes from the perspective of the RDTR planning document, which has a direct impact on the area. The plan was determined without neither carefully considering the key values of the Krapyak District nor anticipating the impact of future planning in the Krapyak District. As a result, specific spatial patterns produced in the area are still fairly prominent with local wisdom and Islamic values. They have a quality that is rarely found in other locations, particularly its association with the alignment of the Sangkan Paraning Dumadi philosophical axis. However, the district is located in a region that is at risk of change. Thus, more cautious efforts should be prepared for the future development plan of this particular district.

\section{ACKNOWLEDGEMENT}

The authors would like to thank the Department of Architecture Engineering and Planning, Faculty of Engineering, Universitas Gadjah Mada, which has provided the opportunity and allowed the authors to utilize the research results of the Bachelor Program Final Project to be published in this journal.

\section{REFERENCES}

[1] M.A.M., Kamal, "Interelasi Nilai Jawa dan Islam dalam Berbagai Aspek Kehidupan", Kalam, Vol. 10, No.1, 19-42, 2016, doi: https:// doi.org/10.24042/klm.v10i1.18
[2] J. Spradley, Participant Observation (Vol. 1), United States of America: Holt, Rinehart, and Winston, 1980, doi: https://doi.org/10.1017/ CBO9781107415324.004

[3] Muhaimin, "Kedudukan Kearifan Lokal Dalam Penataan Ruang Provinsi Bali", Jurnal Penelitian Hukum De Jure, Vol. 18, No. 1, pp. 59-71, 2018, DOI: http://dx.doi.org/10.30641/ dejure.2018.V18.59-71

[4] S. Hadi, E. Soetarto, \& S. Sunito, "Desa Pesantren Dan Reproduksi Kiai Kampung", Analisis Jurnal Studi Keislaman, Vol. 16, No. 1, 33 -66, 2016, doi: https://doi.org/10.24042/ ajsk.v16i1.736

[5] M. Sofer, "The Rural-urban Fringe: Theoretical Issues and Israeli Experience", Landscape and Geodiversity, issue 1, 1-8, 2014.

[6] Y. E. Putrie, \& L. Maslucha, "Seting Perilaku dan Teritorialitas Ruang Sebagai Perwujudan Adab di Masjid Gading Pesantren Kota Malang", El Harakah Jurnal Budaya Islam, Vol. 15, No. 2, pp.15, 2013, DOI: https://doi.org/10.18860/ el.v15i2.2765.

[7] Haryadi \& B. Setiawan, Arsitektur Lingkungan dan Perilaku. Yogyakarta: Gadjah Mada University Press, 2010.

[8] F. S. Chapin Jr., Urban Land Use Planning. Urbana: University of Illinois Press, 1965.

[9] A. Rapoport, Human Aspects of Urban Form, Oxford: Pergamon Press Ltd, 1977.

[10] J. Lang, Creating Architectural Theory: The Role of The Behavioral Sciences in Environmental Design. New York: Van Nostrand Reinhold Company Inc, 1987.

[11] M. S. Hakim, "Perbedaan antara Ibadah Mahdhah dan Ibadah Ghairu Mahdhah", Muslim.or.id., 2019, http://muslim.or.id/46004 perbedaan-antara-ibadah-mahdhah-dan-ibadahghairu-mahdhah-bag-1.html, (Accessed 17 May 2019).

[12] M. Niam, "Tiga Level Syariat dan Cara Memaknainya", NUOnline, 2015, http:// www.nu.or.id/post/read/63130/tiga-level-syariat -dan-cara-memaknainya, (Accessed 4 December 2018).

[13] R. A. Sudrajad, Pengaruh Aktivitas Keagamaan Islam terhadap Aspek Sosial-Budaya Kawasan Krapyak. Bachelor Program Final Project. Urban and Regional Planning Program. Department of Architecture and Planning. Faculty of Engineering, Universitas Gadjah Mada, 2019. 